\title{
CONDITIONS FOR THE DEVELOPMENT OF THE CRUISE SHIP MARKET IN SZCZECIN - RESEARCH RESULTS
}

\section{MONIKA TOMCZYK}

University of Szczecin, Faculty of Management and Economics of Services, POLAND

e-mail: monika.tomczyk@wzieu.pl

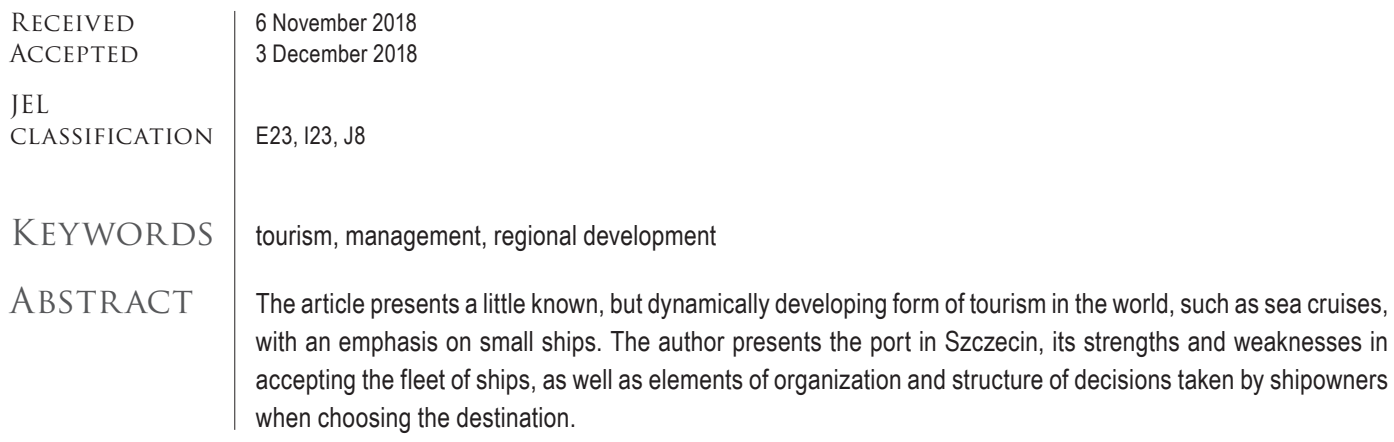
with an emphasis on small ships. The author presents the port in Szczecin, its strengths and weaknesses in accepting the fleet of ships, as well as elements of organization and structure of decisions taken by shipowners when choosing the destination.

\section{Introduction}

The cruise market is a constantly growing but highly competitive market - also in The Baltic Sea region. The market is dominated by a few large operators, operating large vessels on established routes and offering standardized touristic activities. In consequence, only the large harbours are capable to provide the necessary infrastructure. Furthermore cities are only marginally profiting from the cruise ships and tourists as the operators 
offer touristic modules themselves (often including activities outside the area) and most money is spent on the ships. Smaller cruise ships are seen as promising "niche"/market segment with potentials also for small and medium sized harbours in the southern Baltic Sea. What are the chances for fulfiling that niche by Szczecin Port and became the destination for cruise liners? This article contains results from research conducted within the project Joint development of Small Cruise Ship tourism heritage products in the South Baltic.

\section{Literature review}

Cruises are traditionally thought of as luxury holidays for the pampered few, R. Cartwright and C. Baird (1999) expose the myth and gives readers an understanding of their importance in the travel market.

In Polish literature, maritime tourism is discussed by M. Mika (2017, pp. 235-243), he distinguishes five forms of it: cruises on cruise ships engaged in near-coastal voyages; cruises on sea ferries; cruises on merchant and cargo ships; sailing trips on seagoing yachts; cruises on seagoing cruises. And the last form - seagoing cruises will be presented in that article. Subject is in intrest of D. Ptaszycka-Jackowska (2012, pp. 29-39) - she describes the tourist fleets of the world and Europe, the directions of the trips and the ports visited, the elements of the organization. In world literature

\section{Method}

The research was divided into three phases: desk research - covered the period 2007-2017 and were conducted in June/July 2017. The primary research carried out during the research trip on the Horizon vessel in August 2017. The voyage included the ports of the southern part of the Baltic Sea - Gdynia, Wismar, Rostock, Sassnitz, Stralsund, Szczecin, Karlskrona, Kalmar. It included studies of both the technical conditions of ports - the so-called waterside management of the port, as well as the onshore part - the port and its location. Interviews with tourists, port operators and ship operators were also conducted. This research consisted of 3 modules: cruise passenger survey, overall opinion survey, tour reflexions on each destination in form of SWOT Analysis

Walking Interviews/Go-Along Interviews/Mobile Interviews (Evans, Jones, 2011; Jones, Bunce, Evans, Gibbs, Hein, 2008). Expert Focus Group Discussions - after each destination on board to share \& evaluate ideas; Unstructured Interviews conducted with harbourmasters, local cruise operators, local tourist guides, city officials.

The third part consisted of structured interviews with shipowners.

\section{Results}

The following section breaks down Szczecin's cruise statistics for the past 10 years. The number of calls and passengers are analyzed as well as the cruise lines which have visited Szczecin.

Figures 1 and 2 illustrate the development over the past 10 years for Szczecin in terms of cruise call and cruise passenger visitation. 


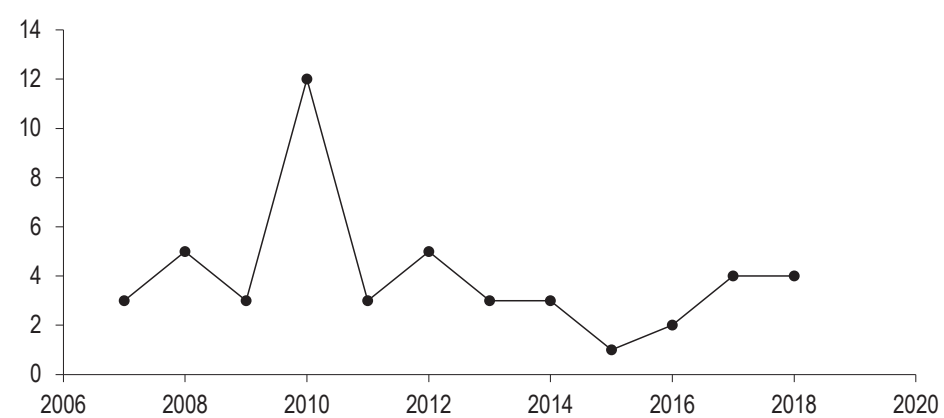

Figure 1. Number of cruise calls in Szczecin's Ports

Source: Data provide by Żegluga Szczecińska.

Szczecin received a total 44 cruise calls between 2007 and 2017, 7 including two calls from a German school ship in 2010 and one from a Norwegian school ship in 2016. According to the information from the Żegluga Szczecińska; 4 calls have been confirmed for 2018 including a call from a Norwegian school ship.

Figure 2 illustrates the cruise passenger visitation in Szczecin per year between 2007 and 2018.

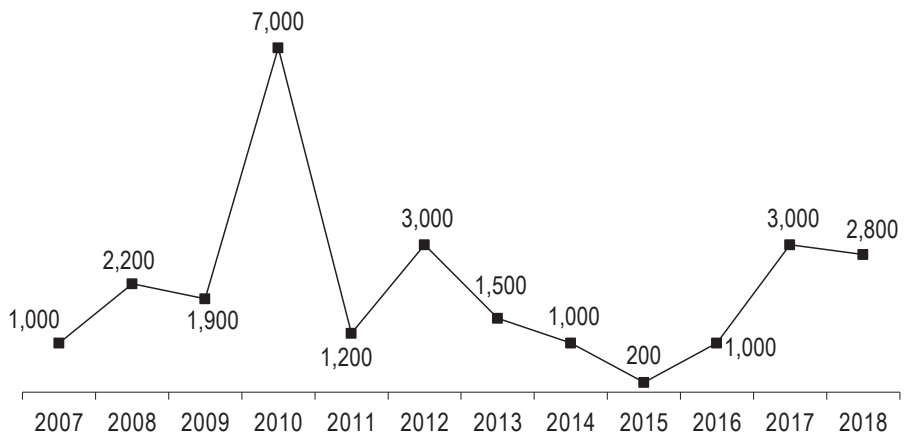

Figure 2. The cruise passenger visitation in Szczecin per year between 2007 and 2018

Source: Datas provide by Żegluga Szczecińska.

When asked about the most important factors for cruise lines when selection cruise destinations the small cruise lines targeted on our survey offered several answers which have been condensed on Figure 3. Nevertheless small cruise lines prioritize the passengers' levels of satisfaction and items related to servicing passengers above all else. This is important to take in consideration when organizing the destination and services.

During the itinerary planning process each small cruise line uses their own internal process but a common procedure includes an internal brainstorming between senior management, itinerary planning, marine and operations, land programs/shore excursions and commercial/marketing and sales departments. 


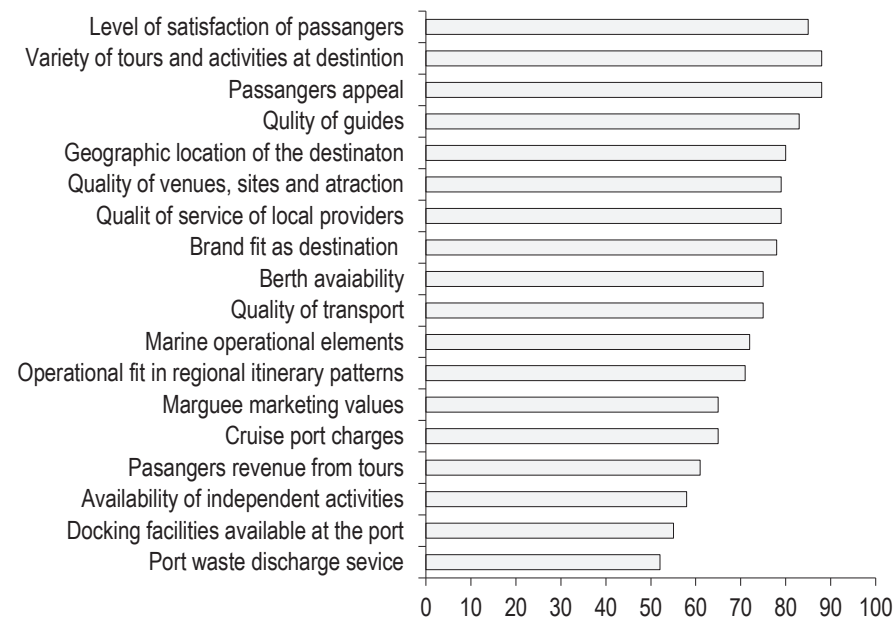

Figure 3. Cruise lines rating factors based on their importance when selecting destinations

Source: own compilation.

Feedback from ports, destination and providers feedback is very useful in the process but it is not critical. Key factors to be taken into account are passenger feedback regarding previous cruise experience in the region, passenger feedback regarding where they would like to sail to and the type of passenger satisfaction expected and revenue to be made on the cruise. Figure 4 below illustrates this cycle.

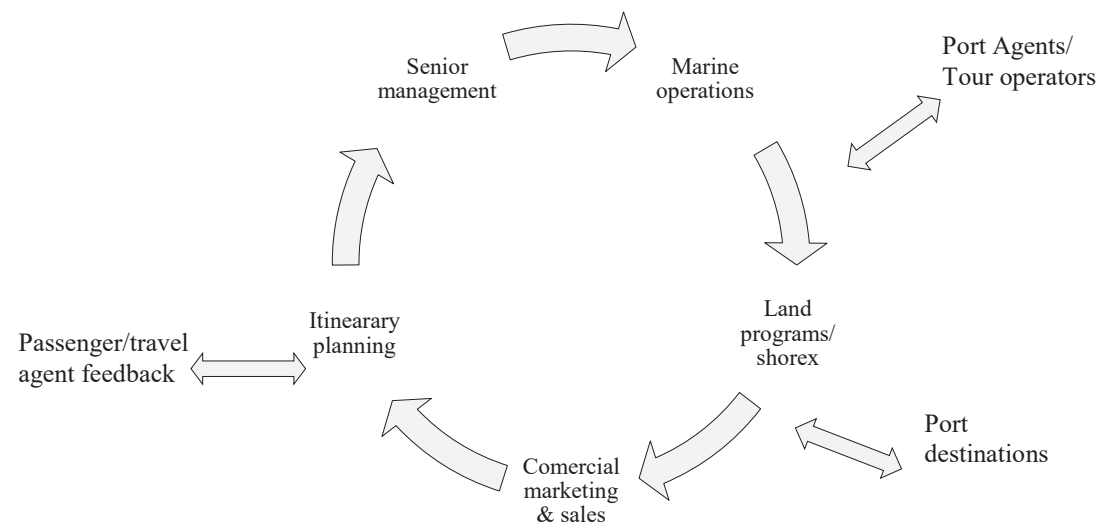

Figure 4. Example of an itinerary planning process and cycle of communication

Source: own compilation.

Most small cruise lines plan their itineraries 36 to 24 months in advance as they want to secure berths especially for smaller and more limited/restricted ports. But many cruise lines still plan their itineraries with 24 to 12 months in advance. Once the itineraries are planned they need to be sold to the public. For small cruise lines 
most of the itineraries are "out for sale" normally between 24 to 12 months ahead of the starting date as these tend to sell fast given the limited availability of cabins on board. The cruises are either sold through travel agents or other sales outlets or directly through the cruise line (via their own district sales managers or their websites).

\section{Resullts supply}

Szczecin as a port has plenty of strong side as:

1. Famous quay in the heart of the city - Wały Chrobrego quay (max draught of $6.5 \mathrm{~m}$ can berth).

2. The advantage is possibility of berthing at both ports with only one chargé (Szczecin \& Świnoujście).

3. Due to the connection with European inland waterway system, Szczecin is also a popular destination for river cruises. The route starts in Berlin, through the Oder-Havel Canal and Pomerania Bay.

4. Szczecin is the closest port for the highest class tourist destination - Berlin - only $144 \mathrm{~km}$ away by highway. This is a unique opportunity for a one-day trip to Germany (as Rostock does for their guests).

5. Long distance of the channel (Świnoujście-Szczecin) could be named as unique opportunity to observe wild nature (eagles, cranes, cormorans, seagulls, grebes, herons etc.), backwaters and landscapes from the deck of cruise ship (together with unique shipyard and port infrastructure it could be sold as attraction journey).

6. Szczecin could become one of tourist excursion destitantions (iconic buildings, castle, shops, architecture, old \& large cementary, museums, and Odra river nature).

7. Szczecin could become the Gateway for Berlin (but there is a need for better infrastructure for trains). Szczecin can aspire to be the staring/ ending point for cruise tourists (Model: fly to Berlin, spend in Berlin 2-3 days, embark in Szczecin for cruise liner.

The challenges that Szczecin face are:

1. Szczecin needs to be more promoted, nowadays there is passive municipal authorities on Sea trade Cruise Global or Sea trade Europe where they could attract cruise operators; Szczecin is not a member of Cruise Baltic Network.

2. Szczecin is the dead-end for sea cruise liners - they lose time to reach Szczecin and then get back at the Baltic sea.

3. Rostock is a strong competitor for Szczecin if it comes for being the gateway to Berlin (the train infrastructure must be better - it used to be approx. 60 minutes now it is 120 minutes).

4. The most representative berth "Waly Chrobrego" needs to be notoriously deepened as well as Odra's river channel.

5. There is lack of tourist infrastucture or terminal for sea cruise liners. Other berths are far from city center (mostly taxi connection only).

\section{Conclusions}

The cruise industry is one of the major areas of tourism growth since the start of the new millennium. Small cruise liners are best target group for less popular port-cities, which is Szczecin. Szczecin to benefit from small cruise should join associations and networks as Network of South Baltic Cities to raise the numbers of calls. Experience form other ports shows that cruise liners can bring a large amount of revenue to local tourism business. 


\section{References}

Cartwright, R., Baird, C. (1999). The Development and Growth of the Cruise Industry. Oxford: Butterworth, Heinemann.

Contribution of Cruise Tourism to the economies of Europe (2010). Brussels-London: GP Wild (International) Ltd., European Cruise Council.

Cruise Ships List, Cruise Companies. Retrieved from: www.cybercruises.com.

Cruise on the Baltic (1929). Warszawa: Żegluga Polska.

Dwyer, L., Forsyth, P. (1998). Economic Significance of Cruise Tourism. Annals of Tourism Research, 25 (2), 393-415.

Evans J., Jones, P. (2011). The walking interview: methodology and place. Applied Geography, 31 (2), 849-858.

Jones, P., Bunce, G., Evans, J., Gibbs, H., Ricketts Hein, J. (2008). Exploring Space and Place With Walking Interviews. Journal of Research Practice, 4 (2). Retrieved from: http://jrp.icaap.org/index.php/jrp/issue/view/8.

Mika, M. (2007) Turystyka morska. In: W. Kurek (ed.), Turystyka (pp. 235-243). Warszawa: Wydawnictwo Naukowe PWN.

Ptaszycka-Jackowska, D. (2012). Morskie rejsy turystyczne nowa gałęzią przemysłu turystycznego. Turyzm, 22 (1), 29-39.

Cite this article aS: Tomczyk, M. (2018). Conditions for the development of the cruise ship market in Szczecin - research results. European Journal of Service Management, 4 (28/1), 337-342. DOI: 10.18276/ejsm.2018.28/1-42. 